\title{
Petro-Democracy: Oil, Power and Politics in Niger
}

Thèse de Doctorat (PhD), Institute for Social and Cultural Anthropology, University of Göttingen, 2018, 367 p.

Jannik Schritt

\section{OpenEdition}

1 Journals

Electronic version

URL: http://journals.openedition.org/anthropodev/760

DOI: 10.4000/anthropodev.760

ISSN: 2553-1719

Publisher

APAD - Association pour l'anthropologie du changement social et du développement

\section{Printed version}

Date of publication: 1 December 2018

Number of pages: $235-236$

ISBN: 979-10-93476-06-3

ISSN: 2276-2019

Electronic reference

Jannik Schritt, "Petro-Democracy: Oil, Power and Politics in Niger », Anthropologie \& développement [Online], 48-49 | 2018, Online since 18 July 2019, connection on 24 September 2020. URL : http:// journals.openedition.org/anthropodev/760; DOI : https://doi.org/10.4000/anthropodev.760

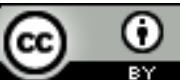

La revue Anthropologie \& développement est mise à disposition selon les termes de la Licence Creative Commons Attribution 4.0 International. 


\title{
Petro-Democracy: Oil, Power and Politics in Niger
}

\author{
Jannik Schritt ${ }^{1}$ \\ Thèse de Doctorat (PhD), Institute for Social and Cultural Anthropology, \\ University of Göttingen, 2018, 367 p.
}

\begin{abstract}
In 2008, Niger signed an oil contract with China National Petroleum Corporation (CNPC) over the Agadem oil block located in the far eastern region of Diffa; and in 2011, they inaugurated the country's first and only oil refinery near Zinder, the second biggest city, situated in the country's south-east. While the inauguration had been planned as a major celebration to mark the coming of oil, it soon became a highly contested political event. That day, with new President Mahamadou Issoufou coming from the capital Niamey (located in the west of the country) to Zinder to mark the occasion, youths set alight tire street barricades and clashed with police. The protests turned into violent riots some days later with youth clashing with security forces in the streets, burning down a police station and looting a bank. Two people were killed and several were injured.
\end{abstract}

Using in-depth ethnographic material collected over 13 months of fieldwork from 2011 to 2014 within the methodological framework of the extended case method, the book takes the event of the oil refinery's inauguration as point of departure to ask the overall research question how oil becomes a source of economic, political and socio-cultural transformation. Critically discussing the resource curse thesis and rentier state theory as well as contributions from an emerging anthropology of oil (introduction), the thesis combines ethnographic analysis with a processual perspective to focus on the process of Niger entering the oil-age, the making of its petro-infrastructure, and the forms of political contestation and resistance that turned around the issue of oil. Based on the tradition of the Manchester School, but reformulated in light of contemporary social theory (chapter 2), the extended case method is used to extend out from the ethnographic description of the inauguration to the historical processes and structural conditions that made the celebration and contestation possible in the first place: first, to the colonial and postcolonial entanglements in the quest for Niger's natural resources (chapter 3 ), and then to political conflicts that were played out on the public political stage after the signing of the oil contract in 2008

${ }^{1}$ E-mail : jannik.schritt@posteo.de

Disponible en ligne : http://hdl.handle.net/11858/00-1735-0000-002E-E4A7-B 
(chapter 4). The main section of the book then focuses on the political arena that formed in Zinder around the inauguration (chapter 5). It shows the political work that turned the opening ceremony into a highly contested event and thereby contributed to making oil into a social and political reality, reconstructing social and political difference and reinforcing patterns of domination. In the next step, abstracting from the ethnographic material, the historically sedimented patterns of domination in Niger are analyzed to sketch the contemporary socio-political configuration of the country (chapter 6). These sedimented patterns of domination are then placed in relation to the politics of the oil infrastructure (chapter 7). Doing so enables an understanding of how the spatial dispersion of the petroinfrastructure in Niger over different administrative regions produced and connected different publics. Furthermore, it makes visible how local historical narratives of repression and marginalization were stitched together to reconfigure collective identities in Niamey, Zinder and Diffa. Finally, the transformation of Niger into an oil state is analyzed, mainly focusing on the period from the beginning of oil production in 2011 until the time of writing in 2018, to understand how entanglements of Western and Chinese economic, political and military forces shape such a development (chapter 8). The empirical findings are then used to theorize on the significatory, temporal, material, and spatial dimensions of an oil state in the making, arguing that oil acts as a "catalyst" rather than as a "blessing" or a "curse". As a catalyst, oil transforms pre-existing structures into a new resource-political configuration. In the case of Niger, a formerly authoritarian uranium-based state was transformed into a "petro-democracy" (conclusion).

The thesis "Petro-Democracy" is of particular interest for all scholars working on Nigerien politics and society or on African oil production. Moreover, it might be of interest for students and senior scholars alike who are interested in African politics and the state, protest movements, civil society, China in Africa, capitalism, and assemblage theory. 